\title{
前立腺肥大症に対するHo:YAGレーザーを 用いた治療
}

棚橋 善克, 豊田 精一, 喜屋武 淳, 坂井 清英,

太田 章三, 小玉 哲也*, 高山 和喜*

東北公済病院泌尿器科

T980-0803 宮城県仙台市青葉区[注分町 2-3-11

TEL 022-227-2211 FAX 022-715-8254

*東北大学流体科学研苔所

Transurethral Prostatectomy using Underwater Shockwave induced by Ho:YAG Laser Irradition

\author{
Yoshikatsu TANAHASHI, Seiichi TOYOTA, Atsushi KYAN, \\ Kiyohide SAKAI, Shozo O'TA, Tetsuya KODAMA* \\ and Kazuyoshi TAKAYAMA* \\ Division of Urology Tohoku Kohsai Hospital \\ *Fluid Research Institute Tohoku University
}

要 旨

私たちは，Ho:YAGレーザーを用いた前立腺肥大症の内視鏡的手術を行っている．この方 法は，Ho:YAGレーザー照射により発生される水中衝撃波を利用して，ナイフのように前立 腺腺腫の切除を行う. 高周波電流を用いる前立腺電気切除術に比べた大きな利点は, 出血が少 なく，低Na血症の合併がないことであり，Nd:YAGレーザーを用いた前立腺焼灼手術に比べ た大きな利点は，術直後から良好な排尿状態が得られることである.

キーワード:前立腺肥大症, 内視鏡手術, Ho:YAGレーザー, 水中衝撃波

\section{Abstract}

Transurethral prostatectomy is performed using Ho:YAG laser in this study. Prostatic tissue is cut by underwater shockwave induced by Ho:YAG laser irradiation. The advantage of this method compared with transurethral prostatectomy using high frequency electrical current is that bleeding is little and there is no possibility of having hyponatremia. Another advantage of this method compared with transurethral 
prostatectomy using Nd:YAG laser is that the force of urinary stream greatly improves just after the operation.

Key words:prostatic hyperplasia, endoscopic surgery, Ho:YAG laser, underwater shockwave

\section{はじめに}

前立腺肥大症とは，前立腺の尿道周囲腺が加齢 とともに腫大し尿道を圧迫するため，排尿障害を 引き起こすに至った病態をいう。前立腺肥大症の 手術療法としては，これまで高周波電流を用いた 切除術が主流であったが, 術後の低Na血症など の合併症が問題となっていた。

最近では，このような合併症を引き起こすこと の無いレーザー照射による前立腺手術の試みがは じまっている.しかし，一般に用いられている連 続波Nd:YAGレーザーは, 組織（水中）での減 衰が少なく組織の深部までエネルギーが及ぶにも かかわらず, 深達度の判定が難しく, 被膜穿孔な よ゙の危険がある. また，術後，照射された組織の 腫張により尿道の閉塞状態が生じ，一過性の尿閉 状態を来たすことも問題点として指摘されてい た.

私たちは，連続波Nd:YAGレーザーに伴う問 題点を解決する目的で，パルス波Ho:YAGレー ザーを応用する事を試みた。 また，超音波パワー ドプラ法（カラードプラエナジー法）を術前に施 行して, 前立腺内の血流を予め把握し, 腺腫内の 太い動脈を確実に閉塞させ効率をたかめること, 尿道周囲の静脈を焼灼し出血を少なくすることを 試みている.

\section{Nd:YAGレーザーとHo:YAGレー ザーの違い}

(1)連続波Nd:YAGレーザー

波長が1.06 $\mu \mathrm{m}$ 之比較的短いため, 組織（水 中）での減衰が少なく，組織中深くエネルギーが 及ぶ（図 1)。したがって，レーザー照射の効果
（組織の変性）は大きいが，被膜第孔などの危険 があった．また，術後，照射部位の腺腫の腫張に より，一過性の尿閉状態を来たすことも問題点と して指摘されている.

(2)パルス波Ho:YAGレーザー

パルス波であるため，レーザーが照射され変性 を受けた組織が，直ちに蒸散あるいは衝撃波の発 生により切除されてしまうため, 变性部の確認が 容易であるという特徴がある。一方，波長が2.06 $\mu \mathrm{m}$ 亡石英ファイバーで伝達できる最大の波長で あるため, 組織（水中）での減衰が大きく，組織 への深達深度は低い（図1)。その一方，被膜穿 孔などの危険は少ない，また，照射とともに組織 が除去されることから，術直後より排尿状態の大 幅な改善が期待される.

\section{Ho:YAGレーザーによる衝撃波発生の} 解明

水中での, Ho:YAGレーザーの照射により，

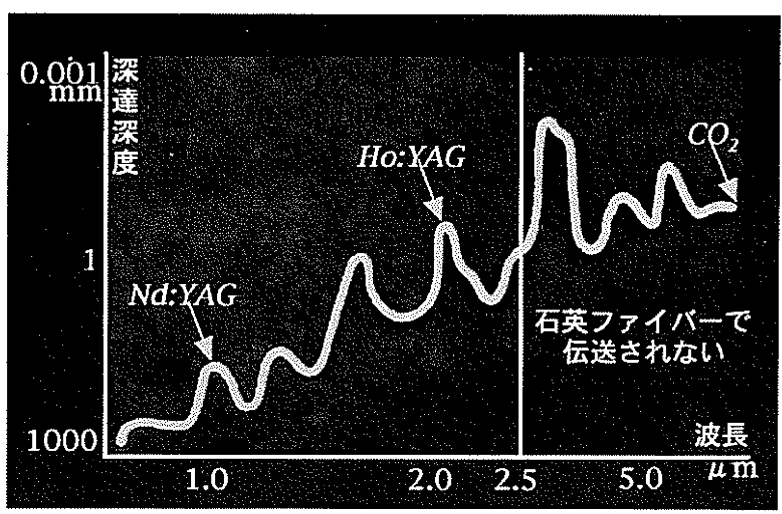

図 1 各種レーザーの組織深達度 吸収度の低いほど，組織深達度が大きい。 波長が約 $2.5 \mu \mathrm{m}$ を越えると，石英ファイ バーでの伝達が不可能となる。 

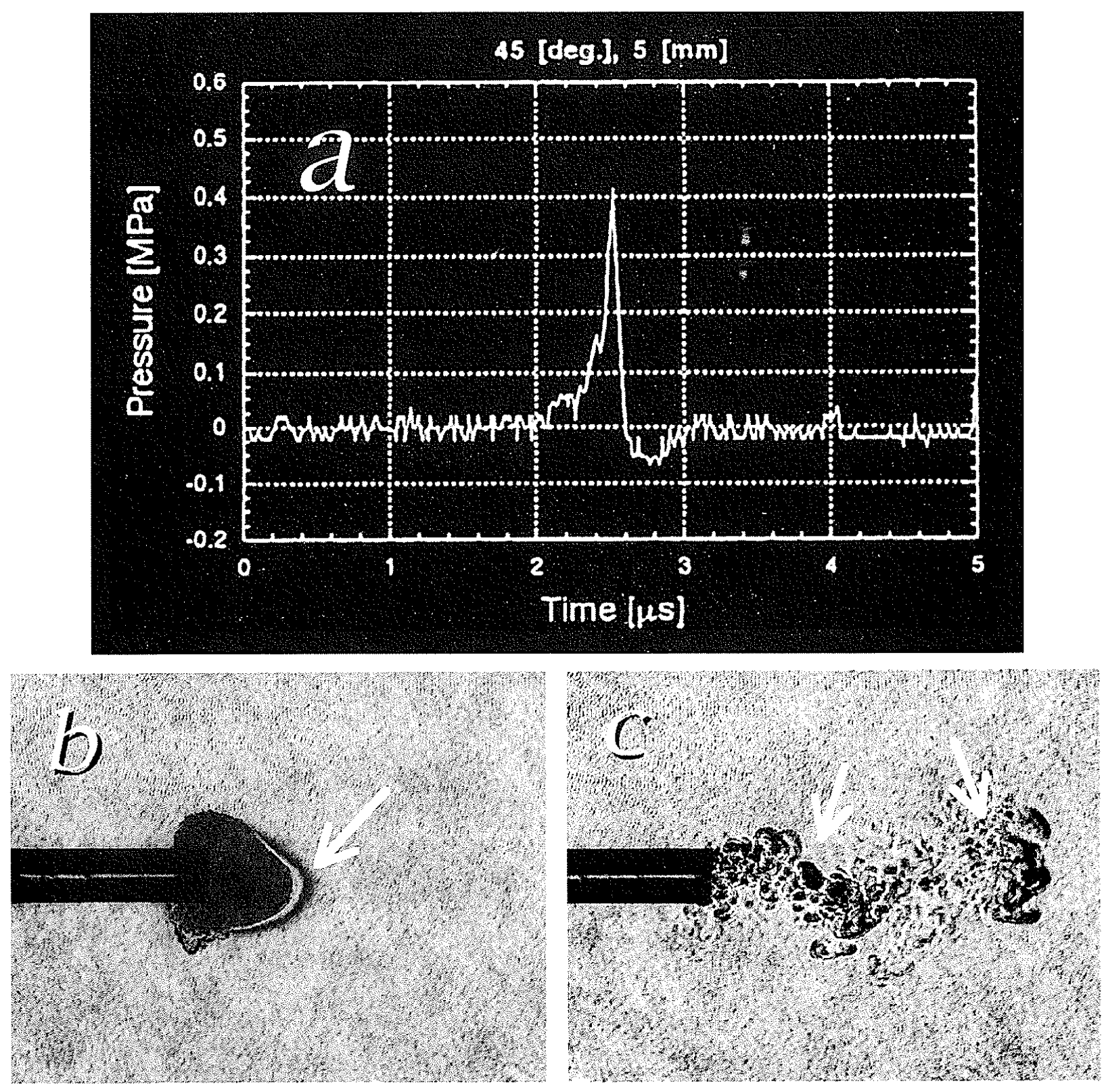

図 2 Ho:YAGレーザーによる衝揧波発生の解明

$\mathrm{a}$ ：鋭いピークを持つ衝慗波形が得られる.

b : マッシュルーム型の衙揧波フロントがファイバー先端に形成されている.

c：衝㨻波により多数の気泡が生成・消退するのにともない，キャビテーション現

象がおきる。

組織は瞬間的に白色変性を来たし断裂する。これ は，水中衝撃波が発生しているためと考え，この 現象の解明を試みた。

実験は，Ho:YAGレーザ一発生装置として，

NIIC社製のMedical Laser System IH102型を 用い, ファイバー先端出力は $20 W$, 水温21.1 22. $8^{\circ} \mathrm{C}$ 条件下で行った.

(1)水中衝擊波の発生
Imotek Messtechnik社製のPVDF needle hydrophoneを用いて，衝撃波波形の検出を試み た.ファイバーの正面では，玨力センサーの破壊 がおきる可能性が大きいので，レーザービームの 方向より少しオフセットした位置で，かつファイ バー先端より数m離れた位置で測定した。

测定結果は，急峻な立ち上がりを持つスパイク 波(衝撃波) で, peak pressureは, ファイバー 


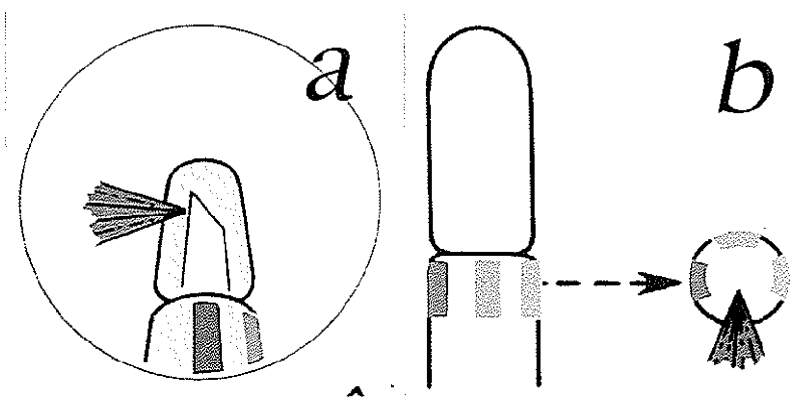

図 3 開発した側射ファイバー

a : $45^{\circ}$ にカットされた端面での全反射に より,レーザービームはほぼ直角 $\left(85^{\circ}\right)$ に向きを変える。

b : 3 色のマーカーにより, レーザービー ムの照射方向の同定が容易となる.

の軸方向に対し $45^{\circ}$ で, ファイバー先端より $3 \mathrm{~mm}$ 離れた位置で0.5 MPa，5 mm離れた位置で0.4 MPaであった（図2a).

(2)水中衝撃波の可視化

レーザー・ホログラフィー干渉計法を用いて， 水中衝撃波の可視化を試みた，水中で $\mathrm{Ho}: \mathrm{YAG}$ レーザーを照射すると，ファイバー前方に衝撃波 フロントが形成され（図 2 b ) それにひきつづい て微小気泡が多数形成・崩壊し, キャビテーショ ンがおこる様子が観察された（図 2 c).

以上のことから，Ho:YAGレーザー照射によ る組織切除のメカニズムは, 衝撃波により発生し た微小気泡の崩壊の際におきる，キャビテーショ ンによるものと推察された。

\section{3. 側射ファイバーの開発}

上記のファイバーの導光系としては石英ファイ バーが用いられている，前立腺の手術においては ファイバーと直交する方向にレーザービームを偏 向させる必要があり， Nd:YAGレーザーによる 治療では側射ファイバーが用いられている。しか し，Ho:YAGレーザーは，Nd:YAGレーザーに 比べpeak powerが大きいので, ミラーあるいは プリズムを用いたNd:YAGレーザーの側射ファ イバーでは，耐久性に問題がある，またここら の側射ファイバーでは，レーザーの照射方向の同
定が難しく，照射方向の決定のために費やす時間 が手術時間のかなりの部分を占めていた，そこ でここれらの久点を補うため，耐久性が高く，さ らに照準のあわせやすい側射ファイバーを開発し た。

(1)開発した側射ファイバーは，石英ファイバー 先端部を約 $45^{\circ}$ にカットし，この部分を石英カプ セルで覆い，このカプセル内に窒素ガスを充垻し た構造とした，レーザー光は，45にカットされ た端面で全反射して，約 $85^{\circ}$ 偏向される（図 3 a).なお，石英ファイバーのcore径は600 $\mu \mathrm{m}$, 被覆を含めた外径は $1.4 \mathrm{~mm}$ で, 先端のカプセルの 外径は2.0 mmである.

(2)レーザーの照射方向はガイド光により確認で きることになってはいるが，実際の内視鏡鏡下の 使用では，尿道粘膜の状態（発赤, 浮腫）によっ てはガイド光が見えにくいことがしばしばあり， 照射方向の確認のために多大な時間を消費する。 そこで，このファイバーには，先端に 3 本の線状 のマーカーを付け，照射方向の確認を容易とし手 術時間を短縮することをもくろんだ．レーザーの 照射方向上マーカーの色との関係は図 3 bのよう になっている。すなわち, 内視鏡的に黄色のライ ンが見えたらレーザーの照射方向は 6 時方向, 赤 色のラインが見えたら 9 時方向, 青色のラインが 見えたら 3 時方向にレーザービームが出ているこ とになる。

\section{4. 超音波パワードプラ法による前立腺内 の血流状態の検討}

前立腺内の血流の状態を観察する目的で, 超音 波ビームと直交した血流も捉えることのできるパ ワードプラ法（カラードプラエナジー法）を施行 して, 前立腺内の血流を予め把握することにつと めた，正常前立腺では，前立腺内血流の検出率は さほど高くはない（図4 a ）が，肥大症では，腺 腫（いわゆる内腺, transition zone) 内部ある いは尿道周囲の血流が著しく増加していた（図 4 b).このうち, 腺腫内の動脈の走行は, 主とし 


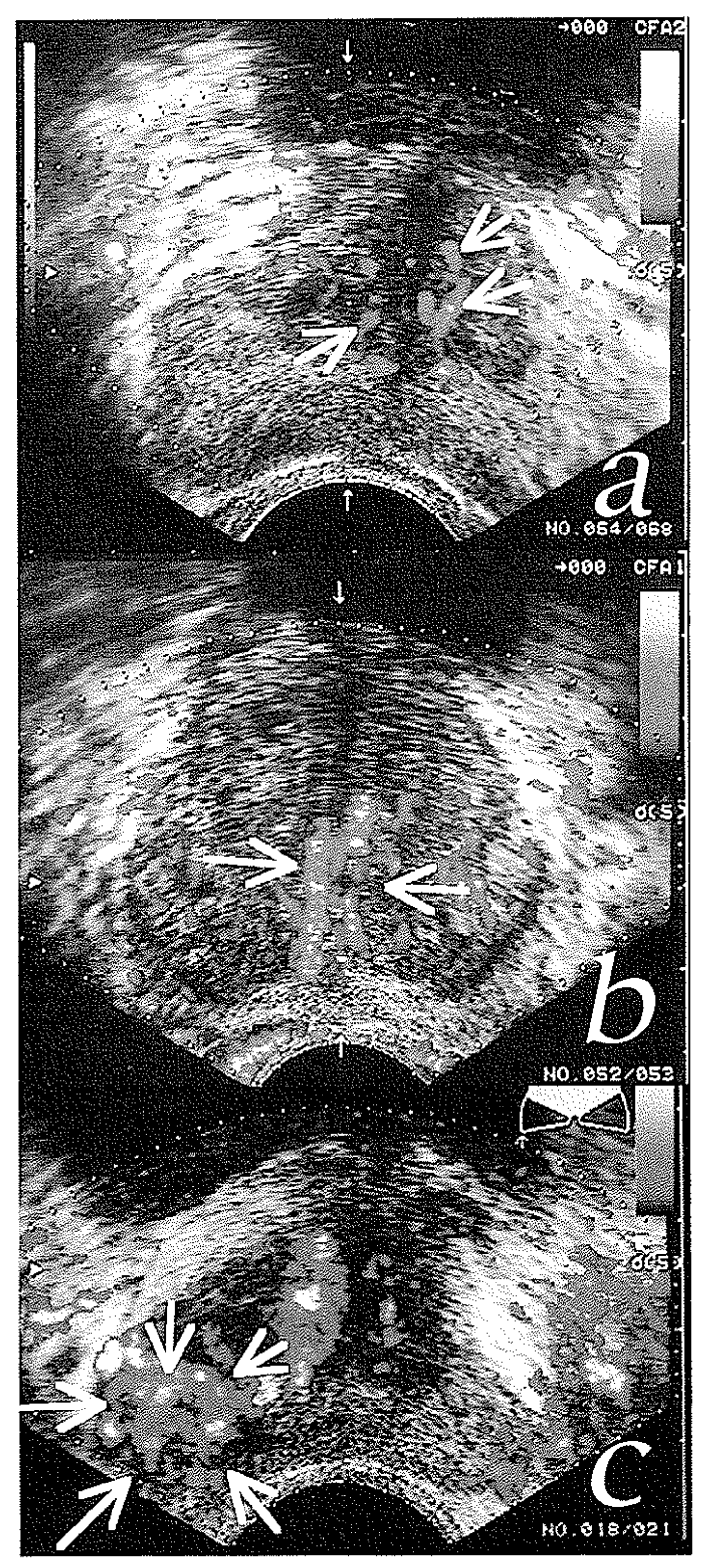

図 4 前立腺内部の血流映像

a：いわゆる内腺（transition zone）に， わずかに血流映像が得られる.

b : 腫大した内腺 (腺腫) および尿道周国 に豊富な血流映像が得られる。

c : 前立腺炎では, 炎症の部位に一致して 豊富な血流が得られる( $\rightarrow$ は，いわゆ る外腺, peripheral zoneでの血流映 像).

て腺腫の前後力向に走行していることが多く, 上 下方向に走行していることは少なかった。また， 尿道周囲の静脈は，やはり前後に走行するが複雑 なネットワークを形成している，ちなみに前立腺 炎では，辺縁部（いわゆる外腺, peripheral zone）での血流が増加している例が多かった
(図 4 c).

\section{5. 臨床応用}

\section{1) 対象症例}

Ho:YAGレーザーによる治療は，20例に行っ

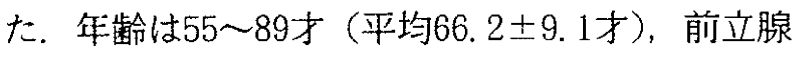
推定重量は19～ $86 \mathrm{~g}$ （平均 $39.5 \pm 19.6 \mathrm{~g}$ ）であっ た。

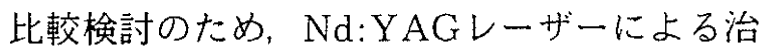
療を行った20例の年齢は，59〜88才（平均73.4 8.5 才), 前立腺推定重量は22 $103 \mathrm{~g}$ (平均 $43.7 \pm$ $2 \mathrm{~g})$ であった。両群の間には, 年齢, 推定重量 に有意の差はない。

\section{2) レーザーによる照射の実際}

(1)レーザー照射に用いるレンズは，視野方向が $0 \sim 5^{\circ}$ のものを用いた。 これは, 視野方向が浅 いレンズの方が，尿道全体を同時に観察できるの でレーザー照射には好都合だからである。

(2)まず，尿道周囲の血管（静脈が主）に対し， 切開ではなく，熱凝固による閉塞を起こさせた. すなわち、レーザープローブを血管から少し離し て，レーザーのスポット径が大きくなるように し，血管の周囲から照射（defocus照射）してい き，血管の熱变性による萎縮・閉塞を起こさせ， 出血が起きにくいようにした。

(3)ついで，腺腫内の血管の凝固をおこなった。 腺腫の大きさ，およびパワードプラ法で得られた 腺腫内の血管の走行に応じて，2点（8 時，10 時）または 3 点（8時， 9 時，10㭙）で, 凝固の 幅が広くなるよう微妙なローリングを加えつつ, プローブを腺腫に接触させながらレーザーを照射 し(図 4 a), 予めパワードプラ法で検知された 腺腫内の動脈を焼灼するようにした。

(4)ついで，プローブを膀胱側から精阜側に引き 抜きながら深く切開を行った，このとき，前立腺 の底部（膀胱に近い側）と尖部（精皁に近い方） は浅めに，中央部は樑めに切開した（図4b). 照射切開の深さは, プローブを引いてくるスピー ドによってコントロールした. 


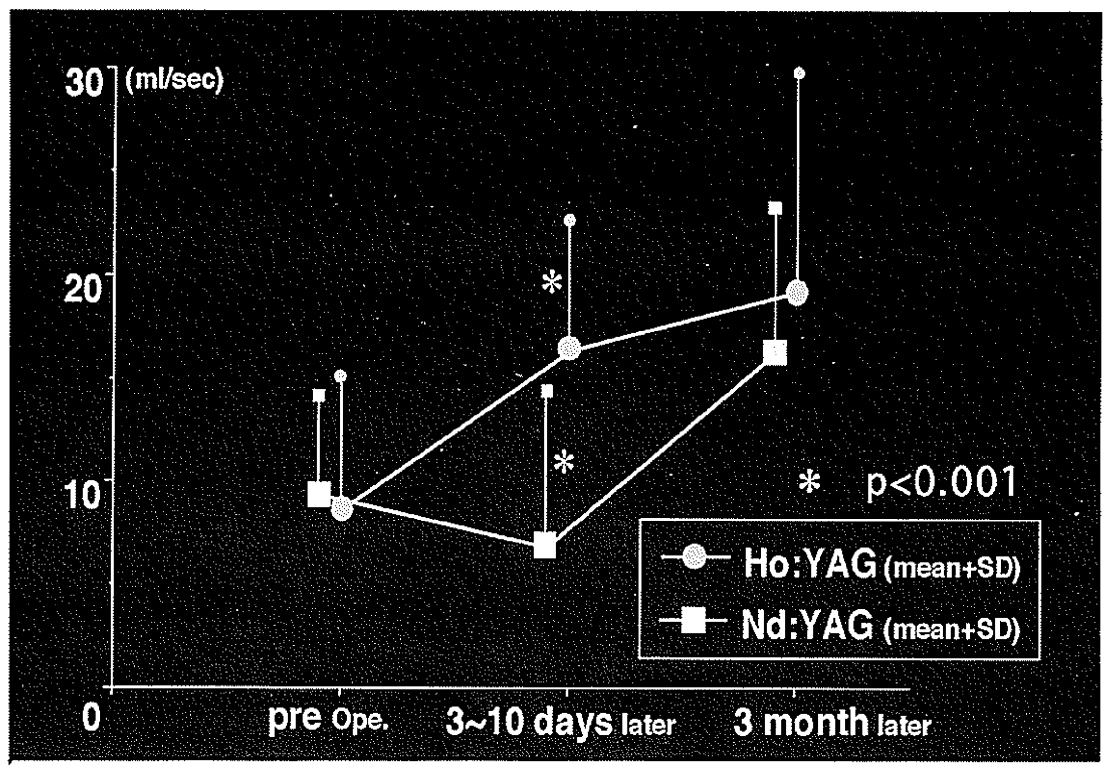

図 5 最大尿流量（Q-max）の推移

Ho:YAGレーザーでは術後早期に改菩している．Nd:YAGレー ザー群では, 術後1 週（3〜10日）で, いったん悪化したのち, 改 善傾向へと向かう.

(5)出血に対しては, 出血点そのものを照射する よりも, 出血点の前後, 上下で, レーザープロー ブを出血点から少し離して, defocus照射すると 容易に止血できた。

\section{3) 臨床成績}

(1) 自覚症状の改善 :

自覚症状チェック項目をスコア化したIPSS(ス コアの高いほど症状が強い）は，Nd:YAGレー ザー群で, 術前21.5土10.6, 術後 1 週（3〜10日 後) $23.6 \pm 14.7$, 術後 3 力月5.2士2.2であった。 Ho:YAGレーザー群では, 術前19.8土6.9, 術後 1 週間8. $2 \pm 5.8$, 術後 3 力月 $6.2 \pm 1.8$ であった。 いずれも術後3カ月では著明に改善していた。し かし, 術後 1 週（3〜10日後）では, Nd:YAG レーザー群はやや悪化しているのに対し，Ho: YAGレーザー群では，最終成績に近い良好な值 を示しており，両群で大きく異なっていた。

(2)他覚所見の改善 :

尿流量検査（最大尿流率）の結果は，Nd:YAG

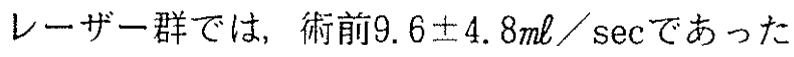
ものが，術後 1 週間（3〜10日後）で7. $2 \pm 7.4$ $m \ell / \sec$ といったん悪化したが, 最終的に術後 3
力月では $16.3 \pm 6 \mathrm{ml} / \mathrm{sec}$ 改善した。一方, Ho:YAGレーザー群では, 術前8. $7 \pm 6 \mathrm{ml} / \mathrm{sec}$,

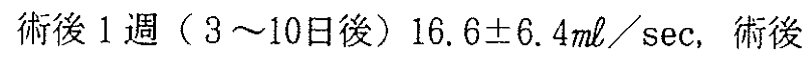
3 力月 $19.4 \pm 10.3 \mathrm{ml} / \mathrm{sec}$, , 術直後上り著明な 改善が見られた。Nd:YAGレーザー群の術前・ 術後 3 力月, Ho: YAGレーザー群の術前, 術後 1 週（3〜10日後）の測定値には，いずれも有意 の差があった（P<0.05）。 また，術1週後の Nd:YAGレーザー群とHo:YAGレーザー群との 測定值の間にも有意差が認められた $(P<0.001$, 図 5 ).

\section{考 察}

前立腺肥大症は，前立腺の尿道周囲腺が加齢之 ともに腫大し，尿道を圧迫するため，排尿障害を 引き起こすに至った病態をいう。前立腺肥大症の 治療としては，薬物療法が第一選択である。しか し，薬物療法が奏効しない場合には，手術療法が 必要となる。手術療法としては，近年開腹手術に 代わって，高周波電流を用いる内視鏡的前立腺切 除術が広く普及している，しかし，この方法で は，高周波電流を用いる都合上，潅流液に電解質 
を調合することができない，そのため，血中 $\mathrm{Na}$ 濃度の低下によるTUR症候群の発生が問題之 なっており，重度の合併症を有する患者には施行 できないという欠点があった.

このような溢路を解決する目的で，レーザー照 射による前立腺手術が試みはじめられている．し かし，一般に用いられている連続波 Nd: $\mathrm{YAG}$ レーザーは，レーザーの波長が $1.06 \mu \mathrm{m}$ と比較的 短いため, 組織（水中）での減衰か少なく組織に 樑くエネルギーが及んでしまうこと，さらに術中 に組織が蒸散し欠損した部分と術後日時を経て壊 死脱落する部分とのギャップが大きいため, 前立 腺被膜の穿孔などの危険があった，また，照射部 の変性した腺腫組織が術後に腫張して，一過性の 尿閉状態を来すことも問題点として指摘されてい る.そこで，私たちは，衝撃波による切開作用 と，熱作用による凝固作用とを併せ持つ，パルス 波Ho:YAGレーザーを応用する事を考えた。

また，前立腺の手術においてはファイバーと直 交する方向にレーザービームを偏向させる必要が あり，一般に側射ファイバーが用いられている。

㑡射ファイバーの形態としては，金を蒸着した金 属ミラーで偏向させるもの，プリズムを用いて偏 向させるものが一般に用いられている。しかし， 前者では耐久性に問題があり，後者ではレーザー ビームの照射方向がわかりにくいという久点が あった。そこで，本研究では，耐久性が高く，さ らに照準のあわせやすい側射ファイバーを，新た に開発した。このファイバーでは，照射方向の確 認が容易で，照射までの準備時間の大幅な短縮が 行えた。 また，石英カプセルが融着されているの で、Nd:YAGレーザー照射時の炭化した組織の 付着が少なく，かつ付着しても簡単に取り去るこ とが可能であった．このファイバーは，偏向法と してミラーやプリズムではなく，端面での全反射 を利用しているので，Ho:YAGレーザーの大き な peak powerに対しても，耐久性は十分なもの であった.

さらに，前立腺内の血流の状態を観察し，これ
らの血管を計画的に凝固・閉塞させ, 治療の安全 性を高めるため, 超音波ビームと直交した血流も 据えることのできる超音波カラードプラエナジー 法（パワードプラ法）を術前に施行して, 前立腺 内の血流を予め把握したのちにレーザー照射を 行ったため, 出血もほとんどみられなかった。

治療結果としては，3力月後の最終成績でみれ ばNd:YAGレーザー群もHo:YAGレーザー群も ほぼ同等の成績で，いずれも満足のいくもので あった。 しかし, 術直後の排尿状態の改善度は, Ho:YAGレーザー群の方がはるかに良好な成績 を示していた。 したがって，カテーテルの抜去後 ゆるやかに効果が出てくるNd:YAGレーザー群 の患者に比べ，退院時にほぼ最大効果に近い排尿 状態となっているHo:YAGレーザー群の患者の 満足度ははるかに高かった。

\section{おわりに}

Ho:YAGレーザーを用いて，安全確実に前立 腺肥大症の治療を行えることが確認できた。今 後，さらに高効率化を計るべく努力をしていきた いと考えている。

\section{文 献}

1）棚橋善克：尿管内走查式超音波映像法之前立腺内 血流同時 2 断面映像法. Innervision, $6: 122-125$, 1991.

2) 棚橋善克：泌尿器科領域におけるカラードプラの 応用・腎 (腫留)。泌尿器外科, $7: 231-242,1994$.

3）棚橋善克：留泌尿器科疾患における超音波ドプラ 法. Annual Review 腎臟1995（長沢俊彦・他 編) PP. 63-71, 中外医学社, 東京, 1995.

4) 棚橋善克・他: Ho:YAGレーザーとカラードプラ エナジー法を用いた安全・確実な前立腺肥大症治 療システムの開発. 共済医報, 46：125-130,1997. 